\title{
Secondary School Teachers' Training Needs Assessment in Mondragon Northern Samar: Basis for Extension Program of the College of Science, University of Eastern Philippines
}

\author{
Olga Dg. Unay \\ Faculty, College of Science, University of Eastern Philippines, Catarman, Northern Samar, Philippines
}

\begin{abstract}
How to cite this paper: Olga Dg. Unay "Secondary School Teachers' Training Needs Assessment in Mondragon Northern Samar: Basis for Extension Program of the College of Science, University of Eastern Philippines" Published in International Journal of Trend in Scientific Research and Development

(ijtsrd), ISSN: 2456-

6470, Volume-3 |

Issue-4, June 2019, pp.339-342, URL: https://www.ijtsrd.c om/papers/ijtsrd23 750.pdf

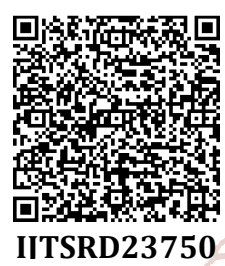

Copyright (C) 2019 by author(s) and International Journal of Trend in Scientific Research and Development Journal. This is an Open Access article distributed under the terms of the Creative ommons

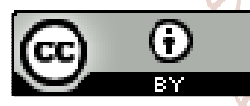
Attribution License (CC BY 4.0) (http://creativecommons.org/licenses/ by/4.0)

\section{ABSTRACT}

The College of Science has been awarded the AACCUP Level II status and is scheduled for a visit for the Level III accreditation. To meet the requirements for the area on extension, an assessment of the training needs of secondary school teachers in Mondragon, Northern Samar was conducted to guide the College of Science for its effective training program for teachers.

The respondents were the public and private secondary school teachers in Mondragon, Northern Samar. The needs assessment questionnaire from OECD Teaching and Learning International Survey (TALIS) was adopted, with few revisions to fit the respondents' characteristics. A Likert-type scale was used to determine the degree of impact in the participation for each area, and to classify the level of expressed needs of the respondents. Frequency counts, ranking, means and weighted means were utilized as statistical treatment tools to determine and describe the level of needs.

This TNA provides a justification for the College of Science's extension program in the different secondary schools in Mondragon, Northern Samar focusing on the following: (1) Skills development: ICT skills for teaching, student discipline and student counselling, school management and administration; classroom management; student assessment practices; teaching in a multicultural setting; instructional practices in subject field/s, and teaching students with special learning needs. (2) Content knowledge on the following subject field/s: Statistics and Probability and Geometry for Mathematics Department; General Chemistry, Laboratory Techniques, Electricity and Magnetism for Physical Sciences Department; Basic instrumentation, Genetics and Evolution for Biological Sciences Department; Disaster Preparedness and Earth Science for Environmental Science Department; and, Application Program like MS Word, Excel, internet and webpage design for Information Technology Department.

Keywords: College of Science, secondary schools, TNA, extension program

\section{INTRODUCTION}

Assessment is a powerful educational tool. It is used to monitor the quality of the school system, evaluate about students, evaluate educational policies and programs and make important educational decisions about students and certify students learning achievement. Are students learning what they are supposed to be learning? To use assessments to improve instruction and student learning, teachers need to take an active role in making decisions about the purpose of assessment.

Training needs assessment (TNA) is the method of determining if a training need exists and if it does, what training is required to fill the gap. The gap between the present status and desired status may indicate problems that in turn can be translated into a training need.

According to Allison Rossett in his book entitled Training Needs Assessment, the purpose of conducting training needs assessment is to seek information about optical performance or knowledge, actual or current performance, feelings of trainees, causes of the problems and solutions to the problems in much perspective.

The needs assessment is the first step in establishment of training and development Program. It is used as a foundation for determining instructional objectives, the selection and design of instructional programs, the implementation of the programs and the evaluation of the training provided. These processes form continues cycle which always begins with a needs assessment. (Miller and Osinski, 1996).

According to Guevara and Nuiqui (2015), the educational sector requires training programs and activities that would fit the roles of the teachers. The responsibilities of education have changed radically as countries transform their educational system to prepare students to function in today's world of rapid technological change and globalization. 


\section{METHODOLOGY}

This Training Needs assessment research used the descriptive-survey method. The respondents of the study were the secondary school teachers of Mondragon N. Samar. There were 4 public and 1 private secondary schools in the municipality of Mondragon N. Samar. A questionnaire was the main instrument, consisting of two parts: respondent' profile and the training needs of the teachers.

The needs assessment questionnaire from OECD Teaching and Learning International Survey (TALIS) was used with a few revisions in order to fit to the respondents.

The responses were classified and described as follows: The degree of impact in the participation for each area were also measured and interpreted as follows:
$3.5-4.0$
Large impact
$2.5-3.49$
Moderate impact
$1.5-2.49$
Small impact
$1-1.49$

The level of expressed needs were classified and interpreted according to the following scales:
$3.5-4.0$
High level of need
$2.5-3.49$
Moderate level of need
$1.5-2.49$
Low level of need
$1-1.49$
No need at all

The data were tabulated. Frequency counts, ranking, means and weighted means were utilized as statistical treatment tools to determine and describe the level of needs.

\section{RESULTS AND DISCUSSION}

There were 156 secondary school teachers in Mondragon Northern Samar. Majority of the respondents (26 or $74 \%$ ) were female. Ten (10) or $29 \%$ were aged between 25 to 30 years old and seven (7) or $20 \%$ were 40 to 45 years old. This is an evidence that the respondents were below 50 years old. A total of thirteen (13) or $37 \%$ were working for 3 to 5 years and one (1) or $3 \%$ was working for 16 to 20 years in service. This can be an indicative that the teachers were working below 20 years in service.

\section{Needs of the Teachers}

Table1. Data on Secondary Teachers' Participation in Professional Development Activities

\begin{tabular}{|c|c|c|c|c|c|c|c|c|c|c|}
\hline Activity & Yes & & No & & \multicolumn{6}{|c|}{ Impact } \\
\hline & f & $\%$ & f & $\%$ & $\begin{array}{c}\text { None } \\
1\end{array}$ & $\begin{array}{c}\text { Small } \\
\text { impact } 2\end{array}$ & $\begin{array}{c}\text { Moderate } \\
\text { impact } 3\end{array}$ & $\begin{array}{l}\text { Large } \\
\text { impact } 4\end{array}$ & $\begin{array}{l}\text { Weighted } \\
\text { Mean }\end{array}$ & INT \\
\hline $\begin{array}{l}\text { Courses/workshops } \\
\text { related to teaching }\end{array}$ & 28 & 80 & & 20 & 0 & 0 & & 28 & 4.00 & $\begin{array}{l}\text { Large } \\
\text { Impact }\end{array}$ \\
\hline $\begin{array}{l}\text { Education } \\
\text { conferences/seminars }\end{array}$ & 33 & 94 & 2 & 6 & 0 & 0 & 8 & 25 & 3.76 & $\begin{array}{l}\text { Large } \\
\text { Impact }\end{array}$ \\
\hline $\begin{array}{l}\text { Qualification/degree } \\
\text { program }\end{array}$ & 20 & 57 & 15 & 43 & Tin 0 & $\operatorname{lin} 50$ & 50 & 15 & 3.75 & $\begin{array}{l}\text { Large } \\
\text { Impact }\end{array}$ \\
\hline $\begin{array}{l}\text { Observation visits to } \\
\text { other schools }\end{array}$ & 15 & 43 & 20 & 57 & $\mathrm{R}_{0}$ & arch 0 & 50 & 10 & 3.67 & $\begin{array}{l}\text { Large } \\
\text { Impact }\end{array}$ \\
\hline $\begin{array}{l}\text { Participation in a } \\
\text { network of teachers } \\
\text { formed specifically for } \\
\text { the professional } \\
\text { development of teachers }\end{array}$ & 25 & 71 & 15 & 43 & 0 & 0 & & 14 & 3.56 & $\begin{array}{l}\text { Large } \\
\text { Impact }\end{array}$ \\
\hline $\begin{array}{l}\text { Individual or } \\
\text { collaborative research }\end{array}$ & 10 & 29 & 25 & 71 & 0 & 0 & 4 & 6 & 3.60 & $\begin{array}{l}\text { Large } \\
\text { Impact }\end{array}$ \\
\hline $\begin{array}{l}\text { Mentoring, peer } \\
\text { observation and coaching }\end{array}$ & 27 & 77 & 8 & 23 & 0 & 0 & 9 & 18 & 3.67 & $\begin{array}{l}\text { Large } \\
\text { Impact }\end{array}$ \\
\hline $\begin{array}{l}\text { Reading professional } \\
\text { literature }\end{array}$ & 30 & 86 & 5 & 14 & 0 & 2 & 12 & 16 & 3.47 & $\begin{array}{l}\text { Large } \\
\text { Impact }\end{array}$ \\
\hline $\begin{array}{l}\text { dialogue with colleagues } \\
\text { on how to improve } \\
\text { teaching }\end{array}$ & 27 & 77 & 8 & 23 & 0 & 0 & 9 & 18 & 3.67 & $\begin{array}{l}\text { Large } \\
\text { Impact }\end{array}$ \\
\hline
\end{tabular}

Table 1 presents data on the teachers' participation in professional development activities. Data from table showed that 33 or $94 \%$ of teachers participated in education conferences/seminars. Professional development activities keep teachers up-to-date on new research on how students learn, emerging technology tools for the classroom, new curriculum resources and more. Teachers need to be updated on the recent teaching techniques, strategies, knowledge and skills that they should possess. A total of 30 or $86 \%$ were involved in reading professional literatures. The best professional development is ongoing, experiential, collaborative and connected to and derived from working with students and understanding their culture. About 28 0r $80 \%$ attended courses/workshops related to teaching. There were 27 or $77 \%$ teachers who experienced mentoring, peer observation and coaching, dialogue with colleagues on how to improve their teaching. Twenty five (25) or 71\% participated in a network of teachers formed specifically for the professional development of the teachers. About 15 or $43 \%$ wanted to observation visits to other schools. An indication that teachers do not like to observe and visit other school because of the requirement for such activities. Ten or $29 \%$ only were involved in individual or collaborative research. All of these activities have a large impact on the teachers as education professionals.

The provision of development activities for teachers vary and should be based on their specific needs to ensure that the teaching-learning process is effective. 
International Journal of Trend in Scientific Research and Development (IJTSRD) @ www.ijtsrd.com eISSN: 2456-6470

Table2. Secondary Education Teachers' Expressed Professional Development Needs

\begin{tabular}{|l|c|c|c|}
\hline \multicolumn{1}{|c|}{ Area } & Weighted Mean & Interpretation & Rank \\
\hline Content and performance standards in subject field/s & 3.89 & High need & 4 \\
\hline Student assessment practices & 3.71 & High need & 8.5 \\
\hline Classroom management & 3.77 & High need & 7 \\
\hline Knowledge and understanding of main subject field/s & 3.86 & High need & 5 \\
\hline Knowledge and understanding of instructional practices in subject field/s & 3.69 & High need & 10.5 \\
\hline ICT skills for teaching & 3.94 & High need & 1 \\
\hline Teaching students with special learning needs & 3.69 & High need & 10.5 \\
\hline Student discipline and behaviour problems & 3.91 & High need & 2.5 \\
\hline School management and administration & 3.83 & High need & 6 \\
\hline Teaching in a multicultural setting & 3.71 & High need & 8.5 \\
\hline Student counseling & 3.91 & High need & 2.5 \\
\hline Over-all Mean & 4.191 & High need & \\
\hline
\end{tabular}

Data analysis indicated in table 2 showed that Secondary teachers expressed high needs for all the listed professional development needs. Among the list, the ICT skills for teaching topped followed by student discipline and student counselling. This implies that teachers need to update the new trends in teaching. The other areas identified to be highly needed are the following: Content and performance standards in subject field/s, knowledge and understanding of main subject field, School management and administration, Classroom management, , student assessment practices and Teaching in Multi-cultural setting, Teaching students with special learning needs, Knowledge and understanding of instructional practices in subject field/s.

Table3. Secondary Education Teachers' Professional Subject Areas Needs

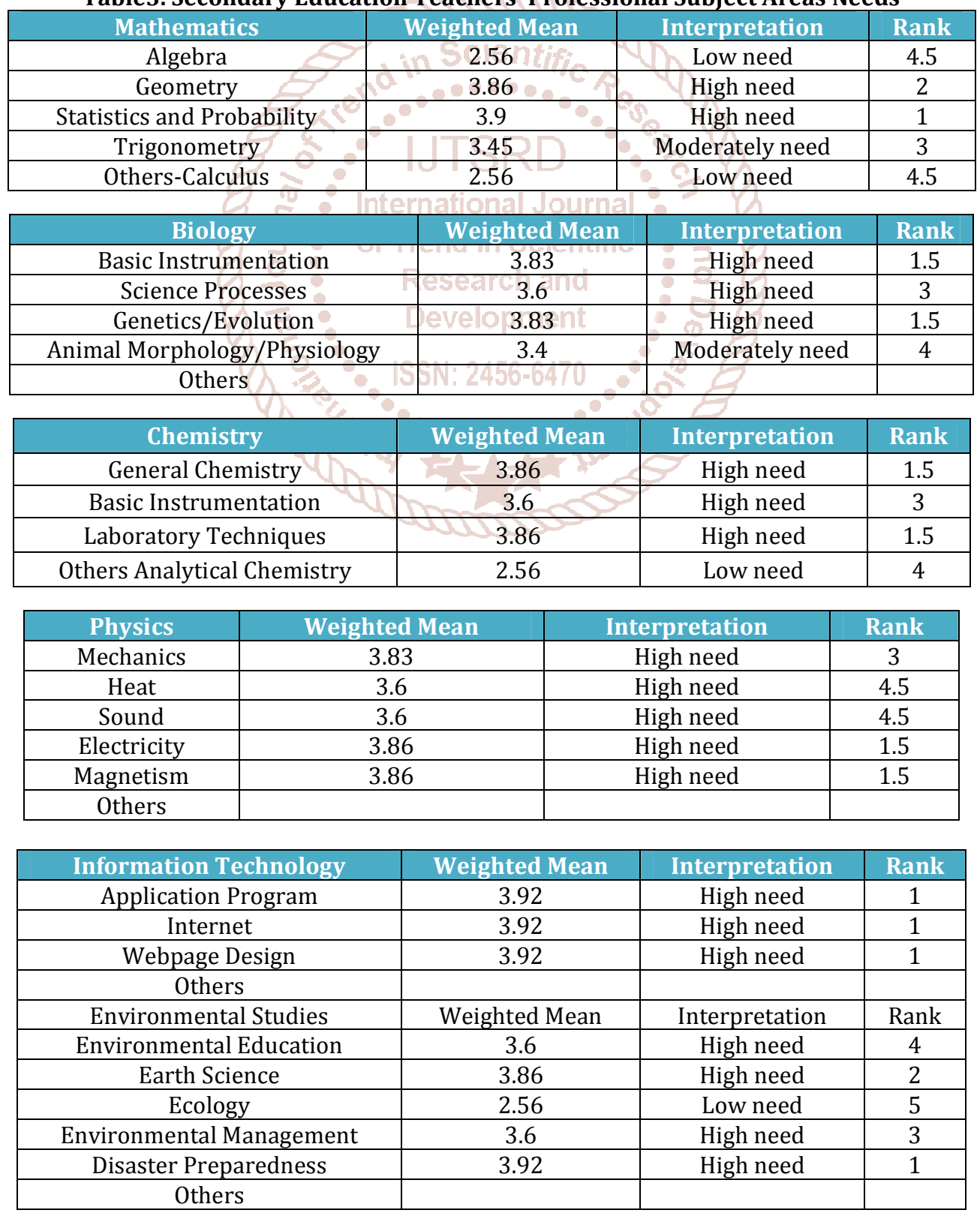


Based on data shown in Table 3, the subject area which ranked 1 in Mathematics is Statistics and Probability. For Biology, the basic instrumentations and genetics/evolution was tied at number 1 . In the field of Chemistry, the areas which ranked one were both General chemistry and laboratory techniques while in Physics, electricity and magnetism ranked number 1 . In Information technology, all three subjects' areas ranked number 1 . This implies that the teachers need most the latest technology expertise in teaching. Education cannot be globally competitive and enhanced without Information and Communication Technology. The disaster preparedness ranked number in Environmental science. This is an indication that disaster preparedness is vital nowadays.

\section{CONCLUSIONS}

This training need assessment study provides a justification for an extension program in the different secondary schools in Mondragon N. Samar.

\section{RECOMMENDATIONS}

The following are the recommendations as needs in the development of the Extension program of the College of Science: (1) ICT skills for teaching. (2) Student discipline and behaviour problems. (3) Student counselling. (4) Content and performance standards in subject field/s. (5) Knowledge and understanding of main subject field/s. (6) School management and administration. (7) Classroom management. (8) Student assessment practices. (9) Teaching in a multicultural setting. (10) Knowledge and understanding of instructional practices in subject field/s. (11) Teaching students with special learning needs.

For the secondary teachers, the following are the recommended subjects in the development of the Extension program of the College of Science. (1) Statistics and Probability and Geometry for Mathematics Department. (2) General Chemistry, Laboratory Techniques, Electricity and Magnetism for Physical Sciences Department. (3) Basic instrumentation, Genetics and Evolution for Biological Sciences Department. (4) Disaster Preparedness and Earth Science for Environmental Science Department. (5) Application Program like MS Word, Excel, internet and webpage design for Information Technology Department.

\section{REFERENCES:}

[1] Rossett, Allison. Trainings Needs Assessment. 1987. Retrieved June 2017 from https://books.google.com > Business \& Economics > Management

[2] Miller, Janice A. SPHR and Diana M. Osinski, SPHR. Trainings Needs Assessment. February 1996. Retrieved June 2017 from https://www.slideshare.net/iyyam_vj/miller-osinski

[3] Guevara, I., V. Nuqui, A. (2016). LCUP Administrators and Teachers Training Needs Assessment: Basis for Developing a Faculty Development Program, Journal of Social Sciences \& Humanities Research, 2(1). 1-14.

[4] Current Challenges in Basic Science Education. Published by UNESCO, France, 2010. Retrieved June 2017

from: unesdoc.unesco.org/images/0019/001914/191425e.p df

[5] Sterling, Plata. DepEd's 2015 Classroom Assessment Reform: A Policy Analysis. 2016. Presented at the DLSU Research Congress 2016, DLSU, Manila.

[6] Bello, Alhaja \& Tijani, A.A. Trainings Needs of Teachers in School-Based Assessment in Anglophone West African Countries. Retrieved June 2017 from: www.iaea.info/documents/paper_2fb24ab5.pdf

[7] Classroom Assessment at Jamaica's Teachers Training Colleges for Primary Teachers: A Needs Assessment. IEQ Project, American Institutes for Research. 2000. Retrieved June 2017 from: www.ieq.org/pdf/Classroom_Assessment-Jamaica.pdf

[8] Maligalig, Dalisay S., Jose Ramon G. Albert. Measures for Assessing Basic Education in the Philippines. Discussion Paper Series No. 2008-16. Philippine Institute for Development Studies, Makati City, Philippines. May 2008.

[9] Organisation for Economic Cooperation and Development (OECD) Teaching and Learning Inventory Survey (TALIS). Retrieved August 2016 from htttp://www.oecd.org > edu > school. 